This item was submitted to Loughborough's Research Repository by the author.

Items in Figshare are protected by copyright, with all rights reserved, unless otherwise indicated.

\title{
What counts as 'the evidence'? A need for an urgent review of injury risk in school rugby
}

PLEASE CITE THE PUBLISHED VERSION

https://doi.org/10.1136/bjsports-2017-098484

\section{PUBLISHER}

(c) The Authors. Published by BMJ Publishing Group

\section{VERSION}

AM (Accepted Manuscript)

\section{PUBLISHER STATEMENT}

This work is made available according to the conditions of the Creative Commons Attribution-NonCommercialNoDerivatives 4.0 International (CC BY-NC-ND 4.0) licence. Full details of this licence are available at: https://creativecommons.org/licenses/by-nc-nd/4.0/

\section{LICENCE}

CC BY-NC-ND 4.0

\section{REPOSITORY RECORD}

Piggin, Joe, and Alan Bairner. 2019. "What Counts as 'the Evidence'? A Need for an Urgent Review of Injury Risk in School Rugby”. figshare. https://hdl.handle.net/2134/28000. 
What counts as 'the evidence'? A need for an urgent review of injury risk in school rugby

Dr Joe Piggin

Loughborough University, School of Sport, Exercise and Health Sciences

Loughborough University, LE113TU,

UK.

j.j.piggin@lboro.ac.uk

$+44(0) 1509226377$

Prof Alan Bairner

Loughborough University, School of Sport, Exercise and Health Sciences

Loughborough LE11 3TU,

UK.

Word count: 1280 .

Keywords: rugby, injury, health promotion, school, public health 


\section{What counts as 'the evidence'? A need for an urgent review of injury risk in school rugby}

In March 2016, an open letter called for the removal of tackling in school rugby union. ${ }^{1}$ In response, the Chief Medical Officers (CMOs) of the UK consulted, gathered evidence and continued with the status quo - they endorsed tackling in school rugby. ${ }^{2}$ The CMOs stated that the evidence does not support the conclusions and recommendations laid out in [the] open letter.' The CMOs relied on a report from the UK Physical Activity Expert Group (PAEG) and a review article by Dr Ross Tucker and colleagues in the BJSM. ${ }^{3}$

We highlight 5 problems with the evidence that the CMOs used to make their decision stemming from a report to the CMOs by the Physical Activity Expert Group (PAEG).

\section{Prevalence of concussion}

In responding to an assertion that 'concussion is a common injury' in rugby the PAEG stated 'It seems that before the sustained programme of education and awareness in rugby concussions were under reported, and it may be now that true concussion is over-reported, making it currently difficult to ascertain where the true incidence lies.' We draw the PAEG's attention to research published in 2016 about attitudes towards concussion in community rugby. ${ }^{5}$ Based on qualitative research with 20 young male rugby players in Ireland, the authors concluded 'non-elite players tend to display an irreverent attitude towards concussion which encourages risky behaviours and underplays, ignores or denies the significance of concussion.' Further, another recent study on community rugby concluded that 'concussion was the most common head injury diagnosis, although it is likely that this injury was underreported'. ${ }^{6}$ In 2016, Hume and colleagues reported that New Zealand community and elite former rugby union players reported a substantially higher number of concussions $(76.8 \%$ and $84.5 \%$ respectively) than non-contact-sport players (23.1\%). ${ }^{7}$

\section{Rugby is a compulsory part of physical education in many schools}

The original letter stated that 'many secondary schools in the United Kingdom deliver contact rugby as a compulsory part of the physical education curriculum from age eleven'. In response the PAEG wrote that 'rugby is not stated as a compulsory part of the PE offer'. A survey of rugby-playing schools in 2015 showed that rugby was 'compulsory in $77 \%$ of responding schools'. ${ }^{8}$ That school rugby was often compulsory, yet associated with injury risk, was an important aspect of the letter and it was not really addressed by the PAEG.

\section{Use of total number of injuries instead of rates relative to participation}

The PAEG stated that 'One of the few examples of injury surveillance, from Oxfordshire, showed that rugby was not the largest contributor to injuries in the under 20s who play sport' [underline in original]. The PAEG compared the statistics for 10-14 year old 
males, with football 'responsible for $36 \%$ of injuries [and] rugby union 18\%'. However, these percentages compared the total number of injuries rather than the injuries relative to the number of participants.

We contend that rugby carries more risk per hour played than football (soccer). According to Sport England, nearly ten times more people in England play football than rugby union. In 2014, 1.8 million people participated in football, whereas 191,900 participated in rugby union. ${ }^{9}$ The relative risk of injury should contribute to policy decisions. For example, the PAEG could have drawn from literature by Nicholl and others (1995) which found that 'the risk of a substantive injury in rugby was three times that in soccer'. ${ }^{10}$ Also, in 2008 Fuller wrote that 'Rugby union is a full contact sport with a relatively high overall risk of injury.' ${ }^{11}$ More recently in 2013, PalmerGreen and colleagues concluded that 'compared with semi-contact team sports such as soccer, rugby union has 4 times the incidence of injury, with the potential for more serious injuries.' 12

\section{Straw-person fallacy linking physical inactivity with removing tackling in schools} The PAEG stated that 'not allowing children to play or be active will be detrimental to their emotional, social, mental and physical health.' There are many ways of children being physical active - limiting tackling in rugby does not prevent children from being physically active.

\section{Contradictory claims about duty of care in schools}

At one point in their report, the PAEG wrote 'Clearly schools, teachers and coaches have a duty of care for children at all times ...'. We draw attention to this statement and the risks of school rugby. Does the PAEG feel they are mitigating risk, risk that can include serious injury, appropriately?

At another point in the PAEG's response, there is reference to the United Nations Convention on the Rights of the Child whereby governments have a duty to protect children from risks of injury. The PAEG stated 'We feel this assertion lies outside of the scope of the Expert Committee'. This seems inconsistent with the PAEG accepting that Schools have a duty of care at all times. In a report to Chief Medical Officers, such contradiction about fundamental ideas is a concern. If the PAEG is unable to engage with this issue, it is prudent to consult others who can offer opinion on this matter.

Beyond these, one final concern worth noting is with how the UK CMOs used the article by Tucker et al to support the findings of the PAEG. The 'Competing Interests' section of the Tucker et al article includes the statement that two of the three authors 'are salaried employees at World Rugby Ltd, the governing body for the sport of Rugby Union globally.' Thus, the only research cited by the CMOs was written by two paid employees of World Rugby, an organisation with a vested interest in increasing participation in schools. 


\section{Conclusion}

We call for the UK Chief Medical Officers to consider and respond to the 5 matters outlined above in relation to the potential harm from tackling in school rugby and in particular, compulsory school rugby. The CMOs should also acknowledge the competing interest of World Rugby, the employer of the scientists who provided the CMOs with expert opinion.

Competing interests: There are no competing interests.

Contributorship: JP conceived and conducted the initial analysis. AB provided critical evaluation, and crafting and shaping of the final rendition.

Acknowledgements: Thank you to those involved in the review process.

Funding info: There are no funders to report for this submission.

Ethical approval information: This analysis did not require ethical approval.

Data sharing statement: Not applicable.

\section{References}

\footnotetext{
${ }^{1}$ Sport Collision Injury Collective. Open Letter: preventing injuries in children playing school rugby, 2016. http://www.sportcic.com/resources/Open\%20Letter\%20SportCIC\%20March1st\%202016.pdf

(Accessed 10 August 2017)

2 UK Chief Medical Officers. RE: Open Letter: Preventing injuries in children playing school rugby, 2016. http://www.sportcic.com/resources/UK\%20CMOs\%20response\%20to\%20open\%20letter\%20on\%20preventin g\%20injuries\%20in\%20children\%20playing\%20school\%20rugby.pdf

(Accessed 10 August 2017)

${ }^{3}$ UK Physical Activity Expert Group. Response to Sports Collision Injury Collective (SCIC) Letter for UK CMOs, 2016.

http://www.sportcic.com/resources/UK\%20CMOs\%20response\%20to\%20open\%20letter\%20on\%20preventin g\%20injuries\%20in\%20children\%20playing\%20school\%20rugby.pdf

(Accessed 10 August 2017)

${ }^{4}$ Tucker R, Raftery M, Verhagen E. Injury risk and a tackle ban in youth Rugby Union: reviewing the evidence and searching for targeted, effective interventions. A critical review. Br J Sports Med 2016;50:921-5.

${ }^{5}$ Liston K, McDowell M, Malcolm D, Scott-Bell A, Waddington I. On being 'head strong': The pain zone and concussion in non-elite rugby union. Int Rev Sociology of Sport. 2016

${ }^{6}$ Roberts SP, Trewartha G, England M, Goodison W, Stokes KA. Concussions and Head Injuries in English Community Rugby Union Match Play, Am J Sports Med. 2017 Feb;45(2):480-487.

${ }^{7}$ Hume PA, Theadom A, Lewis GN et al. A Comparison of Cognitive Function in Former Rugby Union Players Compared with Former Non-Contact-Sport Players and the Impact of Concussion History, Sports Medicine. 2016. doi:10.1007/s40279-016-0608-8

${ }^{8}$ Nyiri P. Re: The unknown risks of youth rugby. BMJ 2015 (accessed 21 Nov 2017).

${ }^{9}$ Sport England. Active People Survey 10 October 2015 - September 2016. https://www.sportengland.org/media/11325/1x30 sport 16plus-factsheet aps10.pdf

${ }^{10}$ Nicholl JP, Coleman P, Williams BT (1995). The epidemiology of sports and exercise related injury in the United Kingdom. BJSM;29(4), 232-238.

${ }^{11}$ Fuller CW. Catastrophic injury in rugby union: is the level of risk acceptable? Sports Medicine. 2008. 38: 97586.
} 
${ }^{12}$ Palmer-Green DS, Stokes KA, Fuller CW, England M, Kemp SPT. and Trewartha, G. Match injuries in English youth academy and schools rugby union: an epidemiological study. American J Sports Med. 2013. 41 (4), pp. 749-755. 